Research Paper

\title{
Heparanase is a novel biomarker for immune infiltration and prognosis in breast cancer
}

\author{
Wen-Jing Yang ${ }^{1}$, Lin Shi ${ }^{1}$, Xiao-Min Wang ${ }^{1}$, Guo-Wang Yang ${ }^{1}$ \\ ${ }^{1}$ Department of Oncology, Beijing Hospital of Traditional Chinese Medicine, Capital Medical University, Beijing \\ 100010, China
}

Correspondence to: Guo-Wang Yang; email: yangguowang bhtcm@126.com, https://orcid.org/0000-0002-0799-3864 Keywords: heparanase, immune infiltration, prognosis, breast cancer

Received: October 19, $2020 \quad$ Accepted: April 29, $2021 \quad$ Published: August 30, 2021

Copyright: (C) 2021 Yang et al. This is an open access article distributed under the terms of the Creative Commons Attribution License (CC BY 3.0), which permits unrestricted use, distribution, and reproduction in any medium, provided the original author and source are credited.

\section{ABSTRACT}

Heparanase (HPSE), an endoglycosidase that cleaves heparan sulfate, regulates a variety of biological processes that promote tumor progression. In this study, we analyzed the correlation between HPSE expression and prognosis in cancer patients, using multiple databases (Oncomine, TIMER, PrognoScan, GEPIA, Kaplan-Meier plotter, miner v4.1, DAVID). HPSE expression was significantly increased in bladder, breast, lung, and stomach cancer compared to matched normal tissues. The increased HPSE expression correlated with poor prognosis and increased immune infiltration levels of B cells, CD8+ and CD4+ T cells, macrophages, neutrophils and dendritic cells in bladder and breast cancer. In breast cancer, the high HPSE expression was associated with basal-like subtypes, younger age (0-40), advanced Scarff-Bloom-Richardson grade, Nottingham Prognostic Index and p53 mutation status. In addition, using a mouse model of breast cancer, our data showed that HPSE upregulated IL-10 expression and promoted macrophage M2 polarization and T cell exhaustion. Together, our data provide a novel immunological perspective on the mechanisms underlying breast cancer progression, and indicate that HPSE may serve as a biomarker for immune infiltration and prognosis in breast cancer.

\section{INTRODUCTION}

Breast cancer is one of the most common tumors and the leading cause of cancer-related deaths in women within the globe [1]. Although improved the strategies for early diagnosis and treatment, the prognosis is still poor, mainly due to inherent aggressive behavior and lack of recognized treatment targets [2]. Therefore, there is an urgent need to develop more sensitive and specific biomarkers for the prognosis of breast cancer patients. In the last 2 decades, immunotherapy including programmed death-1 (PD-1), cytotoxic T lymphocyte associated antigen 4 (CTLA4), and programmed death ligand-1 (PD-L1) inhibitors, demonstrated major breakthroughs and became the major therapeutic approach in solid tumors, such as non-small-cell lung carcinoma (NSCLC) and malignant melanoma [3, 4]. Breast cancer, harboring lots of activated tumor- infiltrating lymphocytes (TILs), is one of the most promising targets of immunotherapy among solid tumors [5-10]. Unfortunately, only a fraction of breast cancer patients responds well to immunotherapy. Since TILs serve as an independent favorable prognostic factor, and a predictive marker of chemotherapy, neoadjuvant therapy, and immunotherapy responses in breast cancer [11-17], identification of specific TILsassociated biomarkers may contribute to development of specific targeted immunotherapies in breast cancer.

The tumor microenvironment (TME), containing tumor cells and non-tumor cells, such as endothelial cells, immune cells, and fibroblasts [18], makes an important impact in tumor metastasis and progression [19-23]. Heparanase (HPSE) is the only mammalian endoglycosidase which can cleaves heparan sulfate (HS), regulates remodeling of the basement membranes 
and extracellular matrix, as well as promotes the release of many HS-related molecules including cytokines, growth factors, and enzymes. HPSE is upregulated in many types of human tumors [24-27], and this elevation contributes to tumor angiogenesis, growth, metastasis, chemoresistance, and poor prognosis [28-32]. Inhibitors targeting HPSE, such as PI-88 (muparfostat), SST0001 (roneparstat), PG545 (pixatimod), and M-402 (necuparanib) have entered clinical trials. Although the role of HPSE in tumor cells has been well documented, its interaction with nontumor cells in the TME has not been sufficiently explored. Recent studies have suggested that HPSE interaction with immune cells which contains T cells, B cells, NK cells, macrophages, neutrophils, and dendritic cells, can have both pro- and anti-tumorigenic roles, depending on the setting [33]. In addition, one research has indicated that by increasing HPSE expression in the ILs, tumors can regulate gene expression of many other tumor and non-tumor cells [34]. Thus, analyzing the interaction between HPSE, breast cancer cells, and TILs might show a novel immunological perspective to understand the mechanisms of tumor progression and further improve the clinical practice in breast cancer therapy.

In this research, we analyzed HPSE expression and the role played in the prognosis of cancer patients. In addition, we investigated HPSE association with tumorinfiltrating immune cells and related immune markers in bladder and breast cancer, and analyzed the HPSE correlation with clinicopathological parameters in breast cancer.

\section{RESULTS}

\section{HPSE mRNA expression in different kinds of human cancer}

To analyze HPSE expression in different kinds of cancer, HPSE mRNA expression in different tumors and matched control tissues were performed using the Oncomine database. The analysis revealed a statistically increased HPSE expression in bladder, brain, CNS, breast, gastric, leukemia, lung, lymphoma, and sarcoma tumors compared to matched normal tissues. However, a decreased HPSE expression was found in colorectal, head and neck, and esophageal cancers (Figure 1A).

To validate the Oncomine results, we analyzed HPSE expression in The Cancer Genome Atlas (TCGA) using the Timer database. As shown in Figure 1B, the HPSE expression was significantly increased in bladder urothelial carcinoma (BLCA), breast invasive carcinoma (BRCA), cholangiocarcinoma (CHOL), esophageal carcinoma (ESCA), lung adenocarcinoma (LUAD), lung squamous carcinoma (LUSC), stomach adenocarcinoma (STAD), and thyroid carcinoma (THCA). In contrast, the HPSE expression was decreased in colon adenocarcinoma (COAD), head and neck cancers (HNSC), kidney renal clear cell carcinoma (KIRC), kidney chromophobe (KICH), liver hepatocellular carcinoma (LIHC), prostate adenocarcinoma (PRAD), rectum adenocarcinoma (READ), and uterine corpus endometrial carcinoma (UCEC).

Comparison of Oncomine and Timer results indicated that the HPSE expression was significantly increased in bladder, breast, lung, and stomach cancer, while it was decreased in colon, head, and neck cancer. Thus, we next analyzed the association of HPSE expression and prognosis in the above cancers.

\section{High HPSE expression impacts prognosis in bladder and breast cancer}

In order to investigate whether the HPSE expression correlates with prognosis in bladder, breast, gastric, lung, colorectal, head, and neck cancer patients, we used the PrognoScan, GEPIA, and Kaplan-Meier plotter databases to evaluate the impact of HPSE expression on survival. The relationships between HPSE expression and prognosis in different cancers using the PrognoScan database is shown in Table 1. Notably, HPSE expression significantly impacted prognosis in bladder and breast cancers. Analysis of HPSE expression and prognosis in different cancers using the GEIPA database showed that high HPSE expression was related to poor DFS and OS rates in bladder cancer (Figure 2B). Analysis of HPSE expression and cancer prognosis using the KaplanMeier plotter database showed that high HPSE expression was related to poor RFS, DMFS, PPS, and OS rates in breast cancer; it was also associated with poor PPS and OS rates in stomach cancer (Figure 2B). Therefore, it is conceivable (confirmed by at least 2 databases) that a high HPSE expression is an independent risk factor, and is associated with poor prognosis in bladder and breast cancer.

\section{HPSE expression correlates with infiltrating immune cells in bladder and breast cancer}

TILs are an independent predict factors of survival in cancer. Therefore, we analyzed whether the HPSE expression was associated with immune infiltration levels in bladder and breast cancer. We assessed the correlation of HPSE expression with immune infiltration levels in bladder and breast cancers by the TIMER database. The results showed that in bladder cancer, the HPSE expression is not related to infiltrating levels of B cells, medium correlation with infiltrating 
levels of $\mathrm{CD} 8+\mathrm{T}$ cells, weak correlation with infiltrating levels of CD4+ $\mathrm{T}$ cells and macrophages, and a strong correlation with infiltrating levels of neutrophils and dendritic cells (DCs). In breast cancer, the HPSE expression showed a medium correlation with infiltrating levels of B cells, CD8+ T cells, CD4+ T cells, and macrophages, and a strong correlation with infiltrating levels of neutrophils and DCs (Figure 3).

To further explore the relationship between HPSE and the infiltrating immune cells, we investigated the association between HPSE and immune cell markers for tumor-associated macrophages (TAM), M1 macrophages, M2 macrophages, monocytes, NK cells, exhausted T cells, Tfh cells, Th1 cells, Th2 cells, Th17 cells, and Treg cells in bladder and breast cancer by the GEPIA database (Table 2). The results showed that in bladder cancer, the HPSE expression had no correlation with Tfh cells, a weak positive correlation with TAM and Treg cells, and a weak negative correlation with M1 macrophages and Th2 cells. The HPSE expression also showed a medium positive correlation with M2 macrophages, monocytes, NK cells, exhausted T cells, and Th1 and Th17 cells in bladder cancer. In breast cancer, the HPSE expression had no correlation with Th2 cells, a weak positive correlation with M1 macrophages, NK cells, and Th17 cells, a medium positive correlation with TAM, exhausted T cells, Tfh cells, Th1 cells, and Treg cells, and a strong positive correlation with M2 macrophages and monocytes.

\section{HPSE expression correlates with clinicopathological parameters in breast cancer}

The correlation between HPSE expression and clinicopathological parameters was explored by the bc-
A

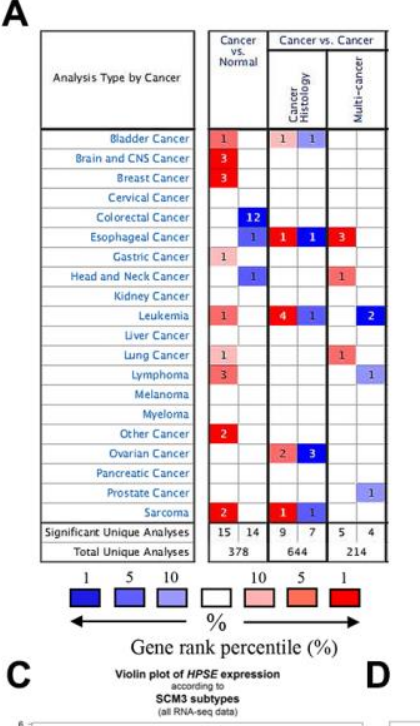

B
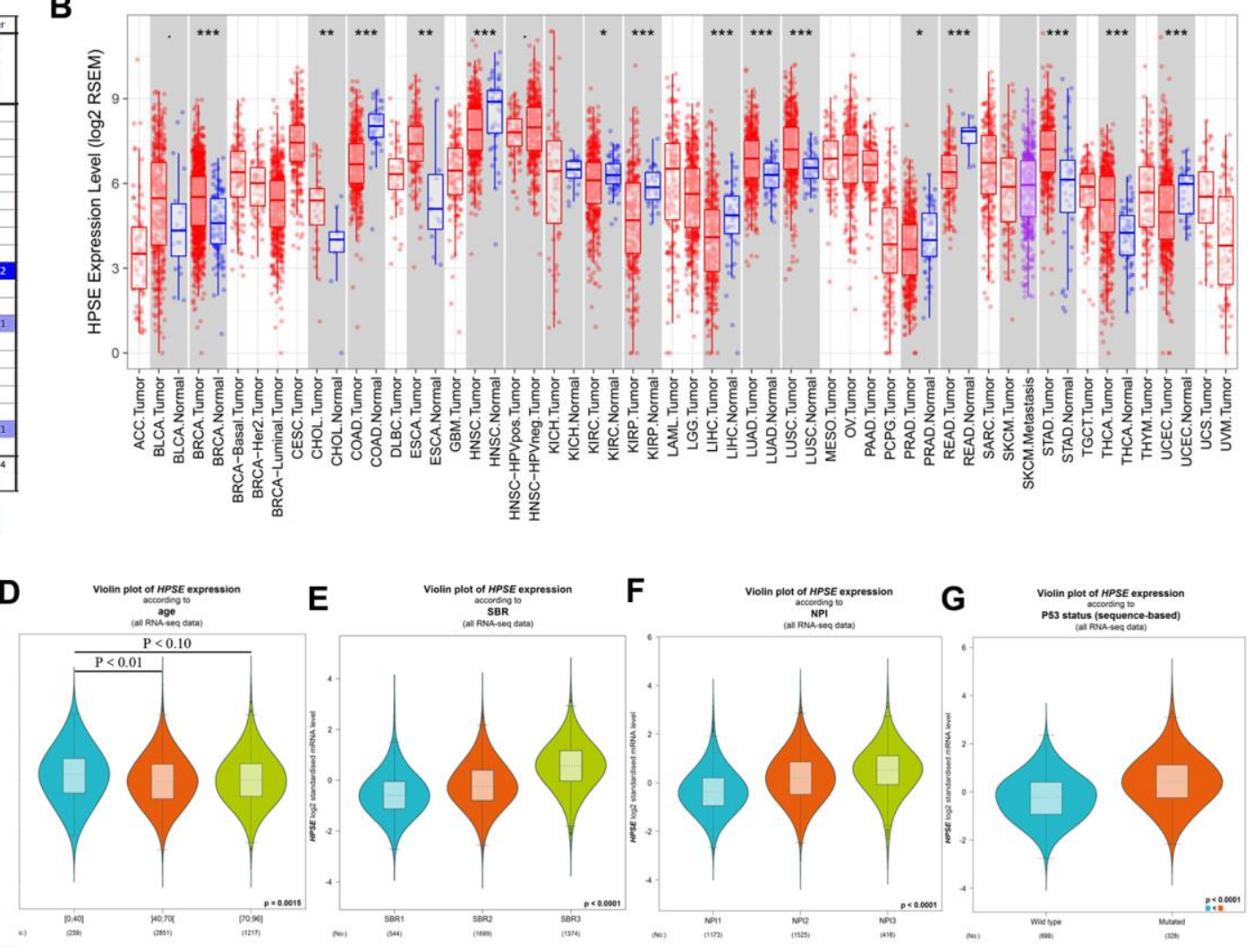

Figure 1. HPSE expression in different types of human cancers, and relationship between HPSE expression and clinicopathological parameters in breast cancer patients. (A) Increased or decreased HPSE in data sets of different cancers compared with normal tissues in the Oncomine database. The graphic demonstrates the numbers of datasets with statistically upregulated (red) or downregulated (blue) expression of the target mRNA. The grid color is determined by the best gene rank percentile for the analyses within the grid. The Arabic number in each grid represents the number of analyses that met the criteria Gene HPSE. The gene rank was analyzed by the percentile of target genes of HPSE in the top of all genes measured. (B) Human HPSE expression in different tumor types in TCGA database determined by TIMER ( $\left.{ }^{*} \mathrm{P}<0.05,{ }^{* * \mathrm{P}}<0.01,{ }^{* * *} \mathrm{P}<0.001\right)$. The results are shown for the relationship between HPSE expression and SCM3 intrinsic molecular subtype (C), age (D), SBR (E), NPI (F), and P53 status (G). 
Table 1. The relationships between HPSE expression and prognosis of different cancers in PrognoScan.

\begin{tabular}{lccccc}
\hline Dataset & Cancer type & Endpoint & N & P-value & HR [95\% CI] \\
\hline GSE13507 & Bladder cancer & Disease Specific Survival & 165 & 0.0259141 & $2.49[1.12-5.56]$ \\
GSE1456-GPL96 & Breast cancer & Disease Specific Survival & 159 & 0.00755681 & $1.93[1.19-3.11]$ \\
GSE1456-GPL96 & Breast cancer & Overall Survival & 159 & 0.0184731 & $1.60[1.08-2.35]$ \\
GSE3494-GPL96 & Breast cancer & Disease Specific Survival & 236 & 0.0195956 & $1.50[1.07-2.11]$ \\
GSE4922-GPL96 & Breast cancer & Disease Free Survival & 249 & 0.0150854 & $1.38[1.06-1.79]$ \\
\hline
\end{tabular}

GenExMiner online tool. HPSE expression was compared with different clinicopathological parameters including intrinsic molecular subtype, age, Scarff-BloomRichardson (SBR) grade, Nottingham Prognostic Index (NPI), and P53 status. For intrinsic molecular subtypes, the HPSE expression in Basal-like subtype was significantly higher than that in Her2+, Luminal A, and Luminal B subtypes; the HPSE expression in Luminal B subtype was significantly higher than in Her2+ and Luminal A subtypes; and the HPSE expression in Her2+ subtype was significantly higher than in Luminal A subtype (Figure 1C). Regarding age, the HPSE expression in 0-40 years group was significantly higher than in 40-70 and 70-96 years groups; no significant difference was found between 40-70 years group and 70-96 years group
(Figure 1D). The SBR histological grade evaluates the degree of duct formation, nucleus pleomorphism, and nuclear division count, while the NPI index stratifies patients into prognostic groups according to lymph node stage, tumor size, and tumor grade. Breast cancer patients with higher SBR grade and NPI tended to express higher levels of HPSE (Figure 1E, 1F). Regarding P53 status, the HPSE expression in mutated group was significantly higher than in wild type group (Figure 1G).

\section{HPSE expression correlates with M2 macrophage polarization and IL-10 in breast cancer}

HPSE target genes in human breast cancer tissues are listed in Table 3; they are discriminated by R. Using the
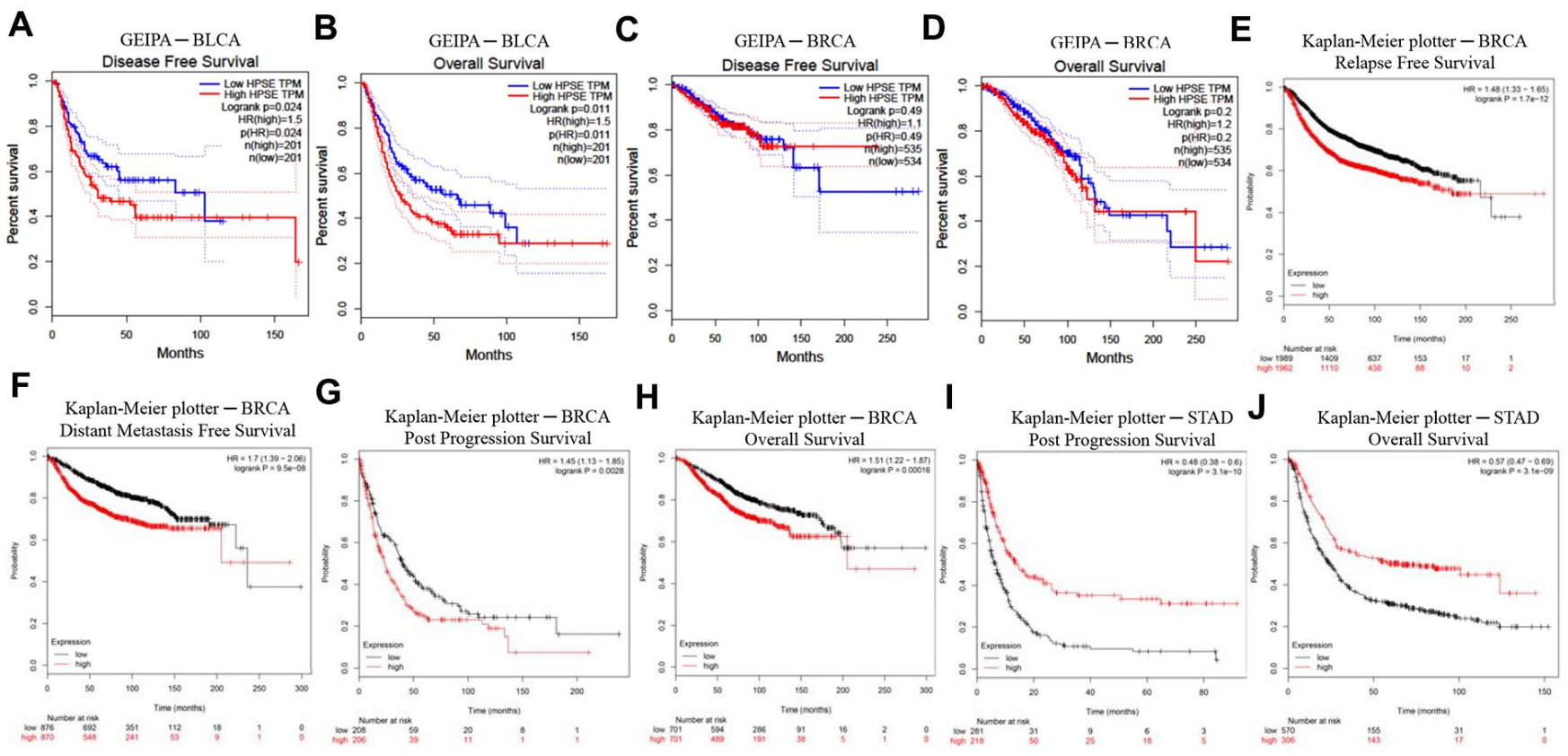

Figure 2. Kaplan-Meier survival curves comparing high and low HPSE expression in different cancer types in GEIPA (A-D) and Kaplan-Meier plotter (E-J). (A, B) Survival curves of DFS and OS in BLCA. (C, D) Survival curves of DFS and OS in BRCA. (E-H) Survival curves of RFS, DMFS, PPS and OS in BRCA. (I, J) Survival curves of PPS and OS in STAD. Bladder urothelial carcinoma (BLCA); breast invasive carcinoma (BRCA); disease-free survival (DFS); distant metastasis-free survival (DMFS); disease-specific survival (DSS); heparanase (HPSE); Gene Expression Profiling Interactive Analysis (GEPIA); overall survival (OS); post progression survival (PPS); relapse-free survival (RFS); stomach adenocarcinoma (STAD). 
DAVID software, we found that a total of 17 GO functions (Biological Processes) were enriched (Figure 4); this was supported by analysis of immune markers (Table 4).

Next, using Human MDA-MB-231-HPSE and MDAMB-231-mock cells which with high and low expression of HPSE (Figure 5A), we validated our data in a mouse model of breast cancer, using mice overexpressing HPSE and a control mock group. Because macrophages usually infiltrate at the edges of tumor tissues, we analyzed the infiltration of macrophages by immunohistochemical staining (IHC) at the tumor tissue edges. IHC staining showed that the HPSE expression correlated with an increased expression of CD163 (Figure 5B) and VSIG4 (Figure $5 \mathrm{C})$, which are markers of $\mathrm{M} 2$ macrophages. Compared with MOCK group, M2 macrophages in HPSE group tended to infiltrate into tumor tissues. In addition, the HPSE expression related to an increased expression of IL-10 (Figure 5D), which is known to induce macrophage polarization into the M2 phenotype.

\section{DISCUSSION}

HPSE, the only mammalian endoglycosidase that cleaves HS, contributes to tumor angiogenesis, growth, metastasis, chemoresistance, and poor prognosis in multiple tumors [24-32]. In this research, we demonstrate that the HPSE expression is obviously increased in bladder, breast, lung, and stomach cancer, but decreased in colon, head, and neck cancer. In addition, our data show that the high HPSE expression is an independent risk factor in bladder and breast cancer, indicating that
HPSE can be used as a prognostic biomarker for bladder and breast cancer. These findings are supported by previous studies demonstrating that high HPSE gene and protein levels are associated with bladder cancer invasion and metastasis [35]. Analysis of HPSE in urine from 282 individuals showed that the urine HPSE levels were elevated during bladder cancer progression [36]. HPSE mRNA levels in bladder cancer tissues related to tumor stage, histological grade, size, number, recurrence and lymph node metastasis [37]. Inhibition of HPSE expression suppressed invasion, migration and adhesion of bladder cancer cells [38]. In addition, HPSE overexpression accelerated the obesity-associated breast cancer progression [39]. However, the HPSE expression in metastatic lesions does not always reflect the expression in primary tumors. In stage I breast cancer patients, a strong HPSE staining was associated with shorter overall survival rates [40]. Tumor growth, vascularization and recurrence were significantly reduced by inhibition the procoagulant activity of HPSE [41]. Furthermore, inhibition of HPSE expression reduced tumor metastasis by reducing extracellular regulated protein kinase (ERK) and phosphorylation of protein kinase B (Akt) [42].

The immune cells in TME play a critical role in tumor progression, and are recognized as an independent predict factor of cancer survival. Moreover, the immune cells- associated HPSE has important pro-tumorigenic and anti-tumorigenic functions [33]. A previous study has indicated that the increased HPSE expression in TILs can regulate gene expression in other tumor and non-tumor cells [34], suggesting that there might be an HPSE-TME crosstalk that can affect occurrence,

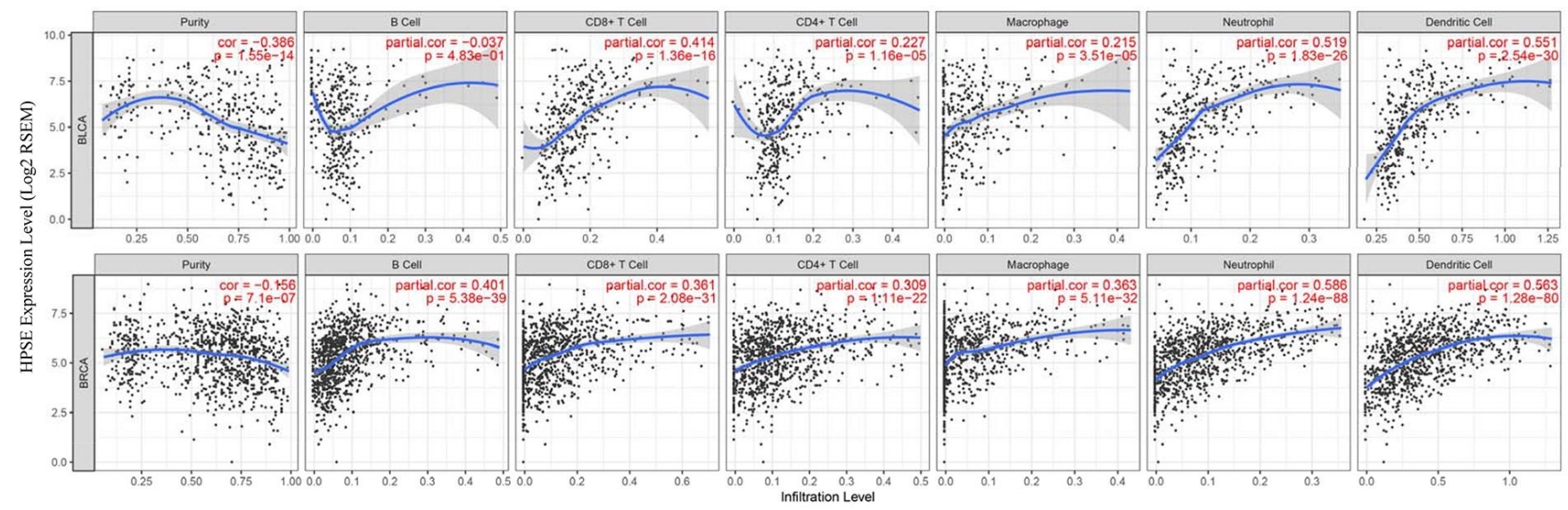

Figure 3. Correlation of HPSE expression with immune infiltration level in BLCA and BRCA. In BLCA, HPSE expression has no correlation with infiltrating levels of B cells, medium correlation with infiltrating levels of CD8+ T cells, weak correlation with infiltrating levels of CD4+ T cells and macrophages, and a strong correlation with infiltrating levels of neutrophils and dendritic cells. In BRCA, HPSE expression has medium correlation with infiltrating levels of B cells, CD8+ T cells, CD4 + T cells, and macrophages, and a strong correlation with infiltrating levels of neutrophils and dendritic cells. 
Table 2. Correlation analysis between HPSE and relate genes and markers of immune cells in GEIPA.

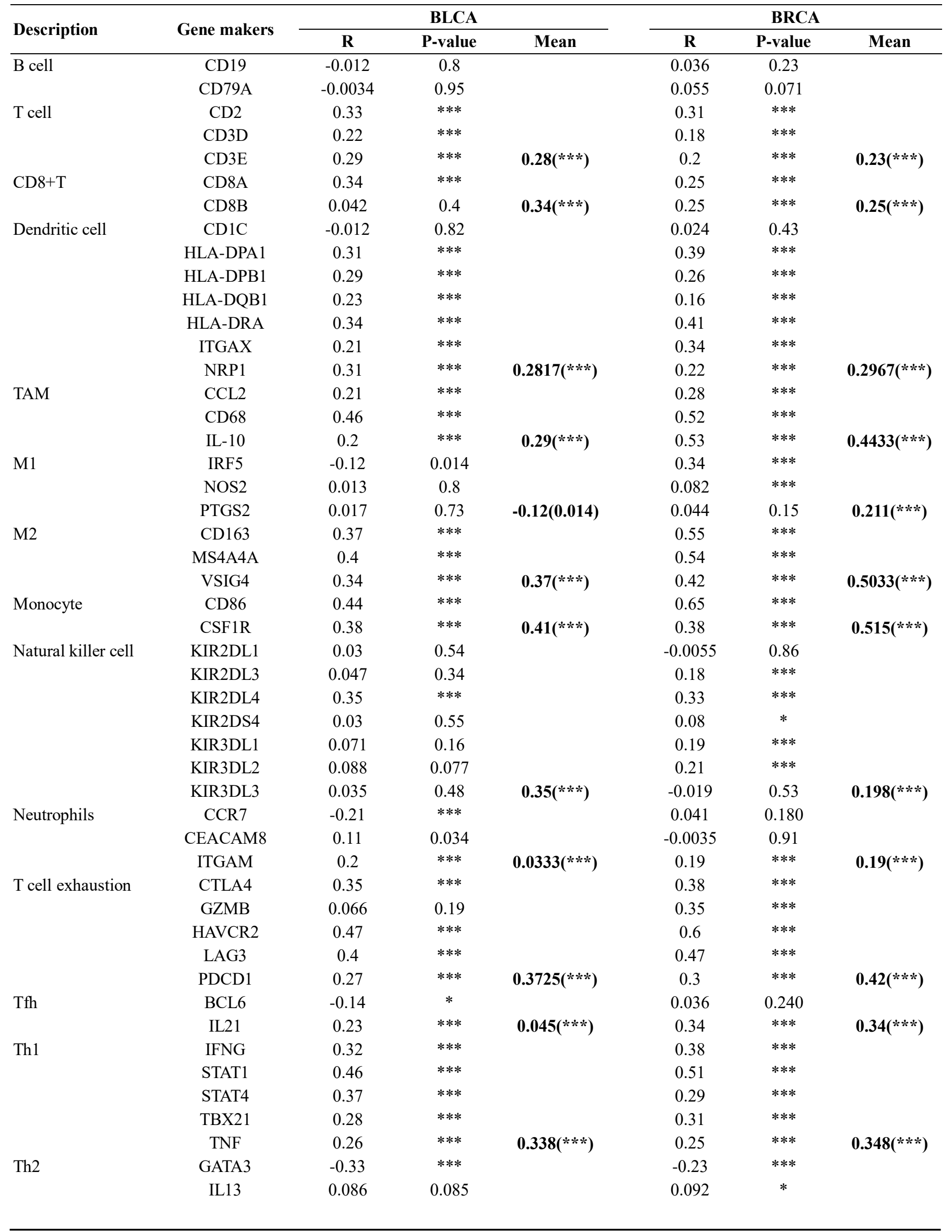




\begin{tabular}{cccccccc} 
& STAT5A & 0.16 & $*$ & & 0.18 & $* * *$ & \\
\multirow{3}{*}{ Th17 } & STAT6 & -0.091 & 0.068 & $\mathbf{- 0 . 0 1 7}(* * *)$ & -0.0018 & $*$ & $\mathbf{0 . 0 1 0 0 5}(* * *)$ \\
& IL17A & -0.047 & 0.34 & & 0.079 & $*$ & \\
& STAT3 & 0.34 & $* * *$ & $\mathbf{0 . 3 4}(* * *)$ & 0.23 & $* * *$ & $\mathbf{0 . 1 5 4 5}(* * *)$ \\
& CCR8 & 0.28 & $* * *$ & & 0.32 & $* * *$ & \\
& FOXP3 & 0.36 & $* * *$ & & 0.33 & $* * *$ & \\
& STAT5B & 0.059 & 0.23 & & -0.0053 & 0.860 & \\
& TGFB1 & 0.13 & 0.0084 & $\mathbf{0 . 2 5 6 7}(* * *)$ & 0.061 & $*$ & $\mathbf{0 . 2 3 7}(* * *)$ \\
\hline
\end{tabular}

TAM, Tumor-associated macrophage; Th, $\mathrm{T}$ helper cell; Tfh, Follicular helper T cell; Treg, Regulatory $\mathrm{T}$ cell; $\mathrm{R}$ value of Spearman's correlation, the absolute value of R, 0-0.09 means no correlation, 0.1-0.3 means weak correlation, 0.3-0.5 means medium correlation, 0.5-1.0 means strong correlation, + means positive correlation, - means negative correlation; MEAN means the average value of relate genes and markers of one specific immune cells with statistical significance. P-value $<0.01$ was considered statistical difference, ${ }^{*} \mathrm{P}$-value $<0.01 ;{ }^{* *} \mathrm{P}$-value $<0.001 ; * * * \mathrm{P}$-value $<0.0001$.

Table 3. Correlation analysis between HPSE and relate genes and markers of immune cells in breast cancer gene-expression miner v4.1.

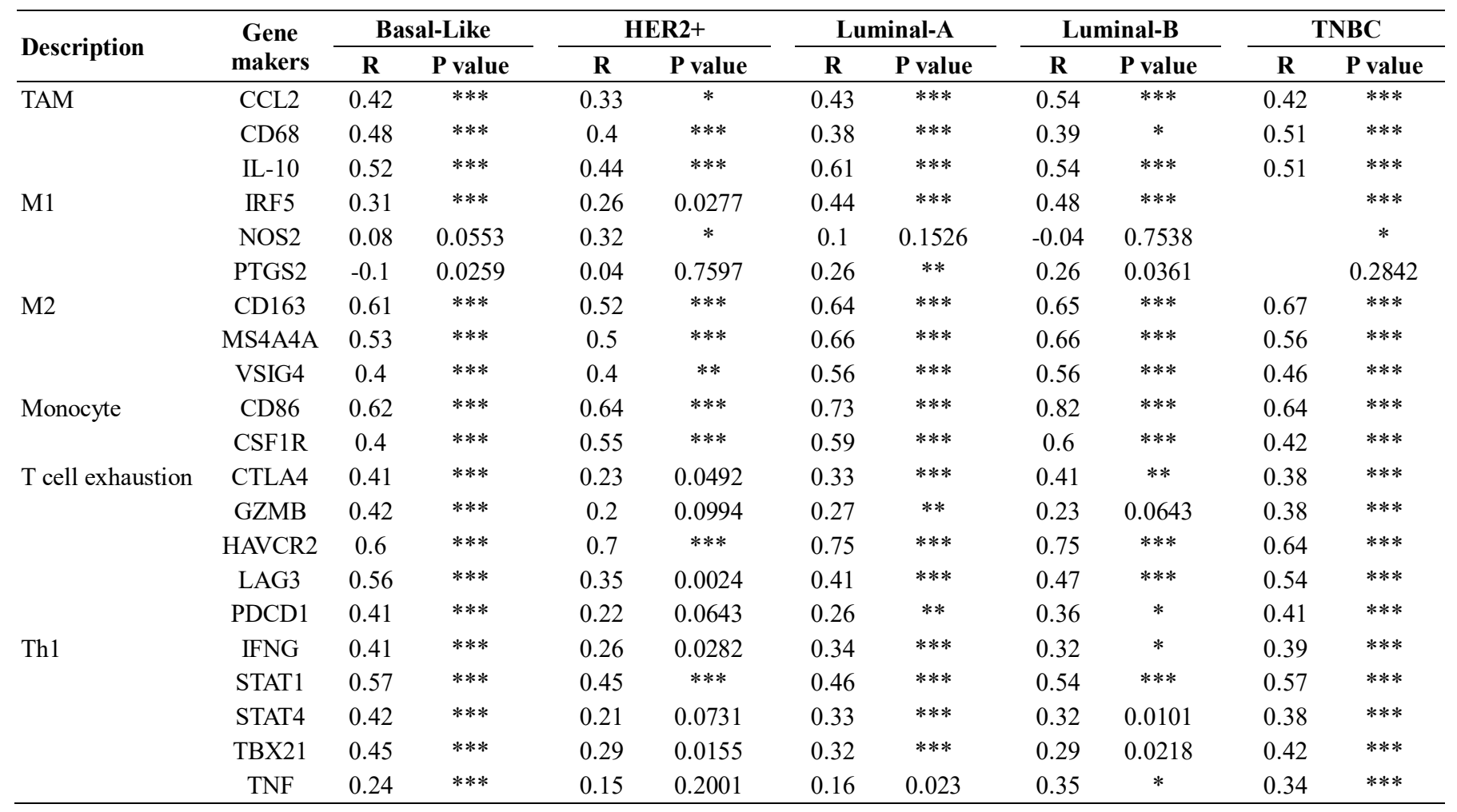

TAM, Tumor-associated macrophage; Th, T helper cell. $R$ value of Spearman's correlation, the absolute value of $R, 0-0.09$ means no correlation, 0.1-0.3 means weak correlation, 0.3-0.5 means medium correlation, 0.5-1.0 means strong correlation, + means positive correlation, - means negative correlation. P-value $<0.01$ was considered statistical difference, $* \mathrm{P}$-value $<$ $0.01 ; * *$ P-value $<0.001 ;{ }^{* * *}$ P-value $<0.0001$

development, and fate of tumors. Our study proved the correlation between HPSE expression and tumorinfiltrating immune cells, and supported the intimate correlation between HPSE expression and immune cell infiltration in bladder and breast cancer.

TAMs are the most plentiful immune cells within the TME [43, 44]. According to their function, macrophages can be divided into $\mathrm{M} 1$ and $\mathrm{M} 2$ phenotypes. The M1 phenotype is characterized by proinflammatory cytokines (IL-1 $\beta$, TNF $\alpha$, INF $\alpha$, IL-6, IL$12, \mathrm{IL}-16)$ and tumoricidal activity. In contrast, the M2 phenotype is characterized by anti-inflammatory cytokines (IL-4, IL-10, IL-13, TGF- $\beta$ ) that promote angiogenesis, tissue remodeling, and repair [45, 46]. Therefore, macrophages play a dual role in tumor growth: on one hand, initiating immune responses against transformed cells; and on the other hand, 
promoting tumor angiogenesis and growth [47-50]. Our data showed that HPSE expression had no or weak correlation with the markers of M1 macrophage, such as NOS2, PTGS2, and IRF5, while HPSE expression had medium or strong correlation with M2 macrophage markers, such as CD163, VSIG4, and MS4A4A. In addition, IL10, a crucial anti-inflammatory cytokine that regulates M2 macrophage polarization, had a strong positive correlation with HPSE expression, indicating that HPSE overexpression might regulate the IL10mediated M2 macrophage polarization. Our results indicated that HPSE might activate Tregs (CCR8, FOXP3, and TGFB1). In addition, HAVCR2 (TIM-3), a crucial gene that regulates $T$ cell exhaustion, positively correlated with HPSE expression, suggesting that HPSE expression might regulate the TIM-3 mediated $\mathrm{T}$ cell exhaustion. These results demonstrated the important role of HPSE in regulating recruitment and activity of immune infiltrating cells in breast cancer, and suggested that HPSE might regulate immune escape in the breast cancer microenvironment.

Macrophages are often found both in primary and metastatic tumors, and contribute to tumor progression [51, 52]. In HPSE knockout mice, macrophages decreased the levels of pro-inflammatory cytokines (TNF- $\alpha$, IL-1 $\beta$, CXCL2, and IL6), and impaired infiltration into lung tumors, which were smaller than tumors in wild type animals [53]. In a mouse model of pancreatic cancer, HPSE overexpression was associated with increased macrophage expression of M2 cytokines IL-6, IL-10, CCL-2, VEGF, and macrophage scavenger receptor-2 (MSR-2), increased tumor size, and increased levels of tumor-infiltrating macrophages [54]. In addition, increased HPSE expression in epithelium has been associated with inflammation and inflammation-associated tumorigenesis, such as inflammatory bowel disease (IBD) [55], pancreatitis [56], and esophageal carcinoma [57]. HPSE has been also suggested as a key regulator of the tumor microenvironment [53] and tumor progression [58]. These findings show that HPSE, regardless of its cellular source, promotes tumorigenesis.

Inflammation-induced HPSE is involved in coupling inflammation and cancer [53]. Toll-like receptors (TLRs) lie upstream of the signaling cascade that leads to cytokine induction by HPSE [59, 60]. HPSE is required for macrophage activation, crosstalk with the tumor microenvironment, and tumorigenesis; the mechanism involves HPSE-mediated TLR activation at the cell membrane, followed by Erk/p38/JNK activation and AP1-mediated transcription [61]. However, the exact mechanism of how HPSE regulates the macrophage phenotype is not understood. Our data indicate that HPSE participates in TLR signaling and JAK-STAT cascade by promoting cytokine production. Specifically, HPSE seems to promote macrophage

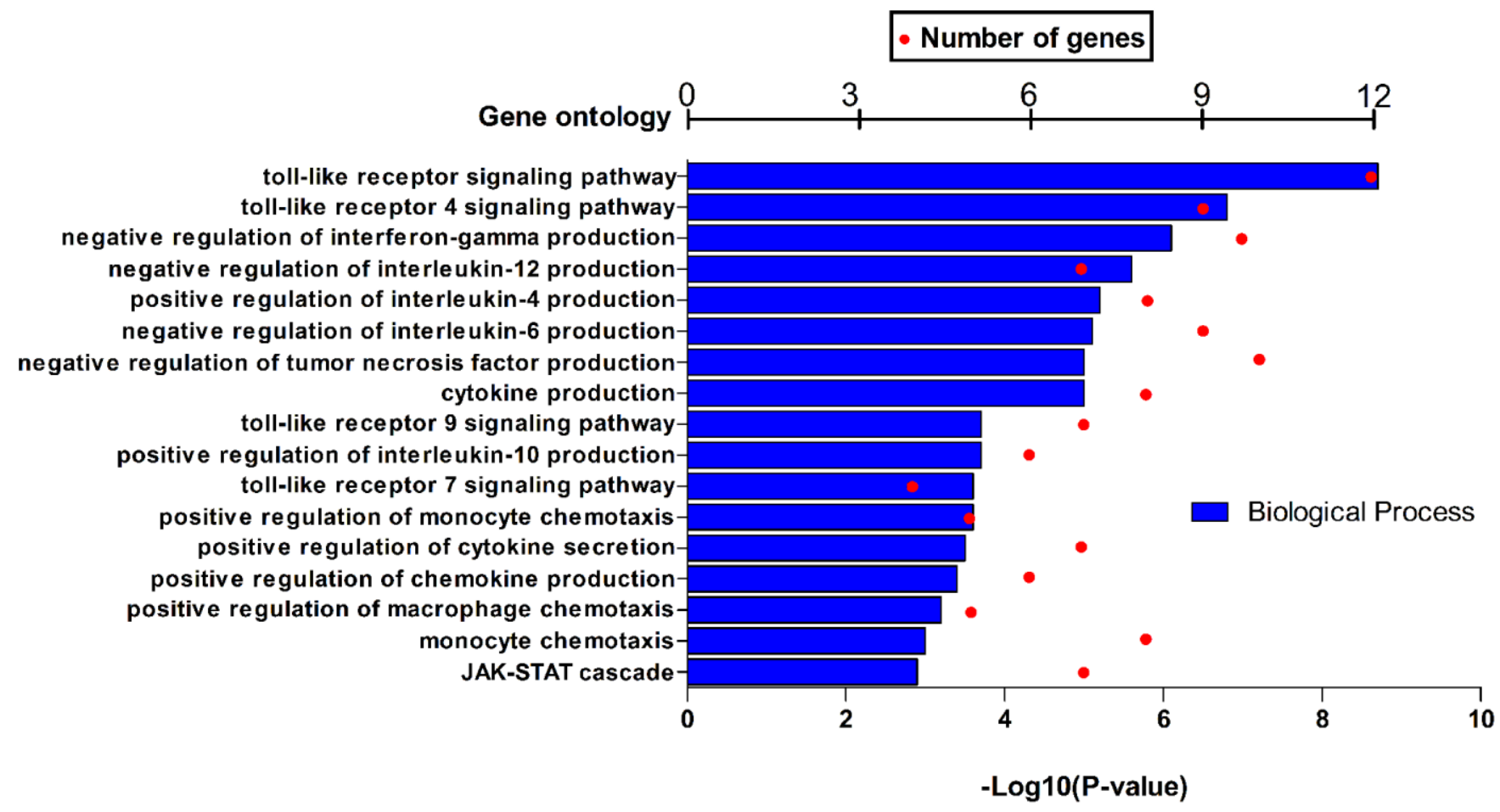

Figure 4. GO function annotations (biological process) for HPSE and target genes in BRCA in DAVID. 
Table 4. HPSE GO function annotations (biological process) for all and intrinsic molecular subtype (RIMSPC) in bc-GenExMiner v4.4.

\begin{tabular}{|c|c|c|c|}
\hline Id & Description & Genes & P-value \\
\hline \multicolumn{4}{|l|}{ Basal-like } \\
\hline GO:0051607 & defense response to virus & $\begin{array}{l}\text { DTX3L, HERC5, IFIH1, IFIT2, IFIT3, ISG15, OAS1, } \\
\text { OAS2, OASL, PLSCR1, RSAD2, RTP4 }\end{array}$ & $1.92 \mathrm{E}-14$ \\
\hline GO:0009615 & response to virus & $\begin{array}{l}\text { CCL8, IFIH1, IFIT2, IFIT3, OAS1, OAS2, OASL, } \\
\text { RSAD2 }\end{array}$ & $1.34 \mathrm{E}-10$ \\
\hline GO:0060337 & type I interferon signaling pathway & IFIT2, IFIT3, ISG15, OAS1, OAS2, OASL, RSAD2 & $2.27 \mathrm{E}-10$ \\
\hline \multicolumn{4}{|l|}{ HER2+ } \\
\hline GO:0010629 & negative regulation of gene expression & CCL3, CCR1, HAVCR2, LGALS9B, LGMN, MSR1 & $8.44 \mathrm{E}-06$ \\
\hline GO:0030502 & negative regulation of bone mineralization & CCL3, CCR1, SRGN & $8.71 \mathrm{E}-06$ \\
\hline GO:0042590 & $\begin{array}{c}\text { antigen processing and presentation of exogenous peptide antigen } \\
\text { via MHC class I }\end{array}$ & FCER1G, IFI30 & $1.94 \mathrm{E}-05$ \\
\hline \multicolumn{4}{|l|}{ Luminal A } \\
\hline GO:0006955 & immune response & $\begin{array}{l}\text { C1QC, CCR1, CD86, CTSS, CXCL10, FCGR1B, } \\
\text { FCGR2B, FCGR2C, GPR65, HLA-DRA, IGHA1, } \\
\text { IGHV3-33, IGHV3-53, IGKV1D-16, IGKV1D-17, } \\
\text { IGKV1D-33, IGKV1D-42, IGKV1D-43, IGKV2D-30, } \\
\text { IGKV3D-15, IGKV3OR2-268, IGKV5-2, IGKV6D- } \\
\text { 21, IGSF6, LST1, MARCH1, NCF4, TLR1, TLR4, } \\
\text { TLR7, TNFSF13B, TRGC2, TRGV3 }\end{array}$ & $6.44 \mathrm{E}-27$ \\
\hline GO:0045087 & innate immune response & $\begin{array}{c}\text { C1QA, C1QB, C1QC, CD14, CLEC7A, CORO1A, } \\
\text { CYBB, FCER1G, HAVCR2, IFI16, IGHA1, IGHV3- } \\
\text { 33, IGHV3-35, IGHV3-53, IGHV3-74, IGHV3OR15- } \\
\text { 7, IGHV4OR15-8, LY86, LY96, LYN, MPEG1, NCF1, } \\
\text { NCF2, RNASE6, TLR1, TLR4, TLR7, TREM2, } \\
\text { TRGV3, TRGV9, TYROBP }\end{array}$ & $3.20 \mathrm{E}-23$ \\
\hline GO:0006958 & complement activation & $\begin{array}{l}\text { C1QA, C1QB, C1QC, IGHA1, IGHV3-33, IGHV3-35, } \\
\text { IGHV3-53, IGHV3-74, IGHV3OR15-7, IGHV4OR15- } \\
\text { 8, IGKV1D-16, IGKV1D-33, IGKV2D-30, IGKV5-2 }\end{array}$ & $2.94 \mathrm{E}-13$ \\
\hline \multicolumn{4}{|l|}{ Luminal B } \\
\hline GO:0051607 & defense response to virus & $\begin{array}{c}\text { CXCL10, GBP1, HERC5, IFI16, IFI44L, IFIH1, } \\
\text { IFIT2, IFIT3, MX1, MX2, OAS1, OAS2, OAS3, } \\
\text { OASL, PLSCR1, RNASE6, RSAD2, TLR3, TLR7, } \\
\text { TRIM22 }\end{array}$ & 4.02E-21 \\
\hline GO:0009615 & response to virus & $\begin{array}{l}\text { CCL8, IFI44, IFIH1, IFIT2, IFIT3, MX1, MX2, } \\
\text { OAS1, OAS2, OAS3, OASL, RSAD2, TRIM22 }\end{array}$ & $5.31 \mathrm{E}-15$ \\
\hline GO:0006954 & inflammatory response & $\begin{array}{l}\text { ADORA3, C3AR1, CCL2, CCL8, CCR1, CLEC7A, } \\
\text { CXCL10, CXCL11, FPR3, HAVCR2, IFI16, LGALS9, } \\
\text { LIPA, NMI, SIGLEC1, THEMIS2, TLR1, TLR4 }\end{array}$ & $3.42 \mathrm{E}-13$ \\
\hline GO:0006955 & immune response & $\begin{array}{c}\text { CCR1, CD80, CD86, CTSC, CTSS, CXCL10, } \\
\text { CXCL11, FCGR1B, FCGR2C, GPR65, IFI44, IFI44L, } \\
\text { IGLV6-57, MARCH1, TLR1, TLR4, TLR7, } \\
\text { TNFSF13B, TRIM22 }\end{array}$ & $5.83 \mathrm{E}-13$ \\
\hline GO:0060337 & type I interferon signaling pathway & $\begin{array}{c}\text { IFIT2, IFIT3, MX1, MX2, OAS1, OAS2, OAS3, } \\
\text { OASL, RSAD2 }\end{array}$ & $4.89 \mathrm{E}-11$ \\
\hline
\end{tabular}




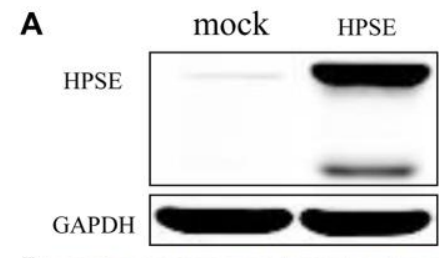

B
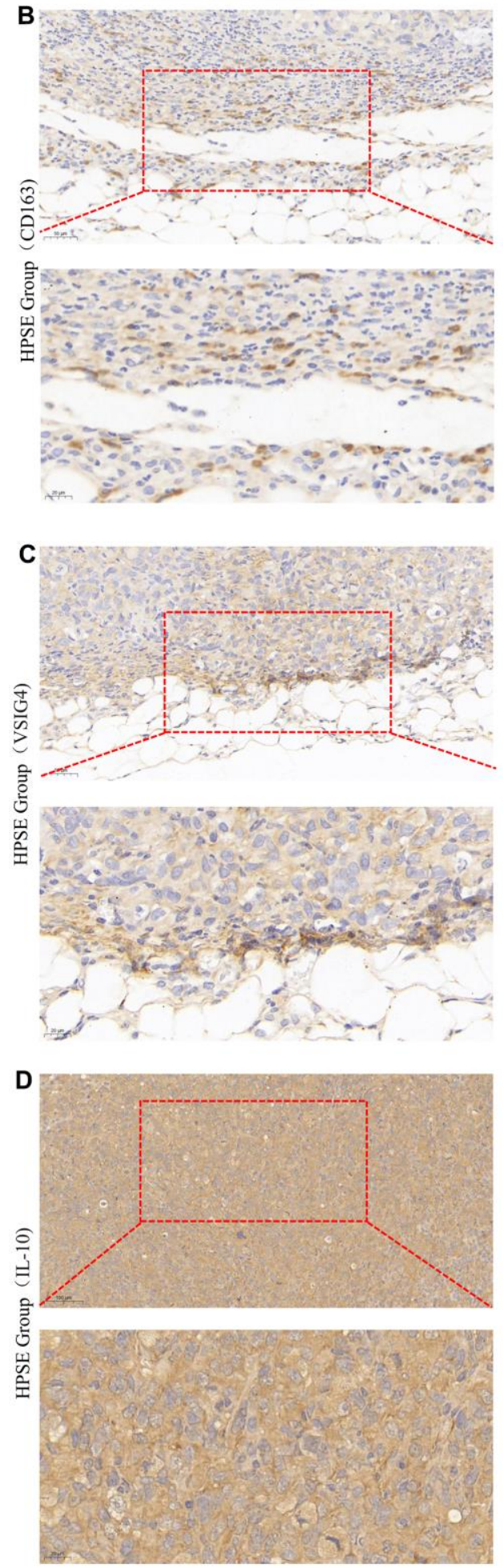
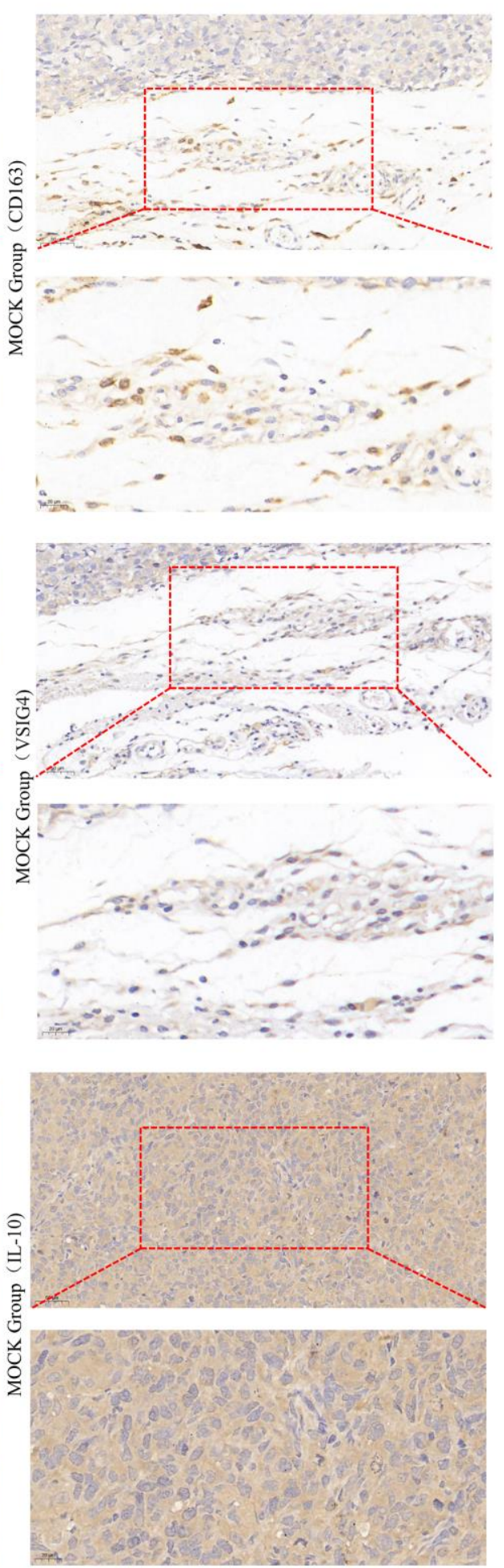

Figure 5. HPSE expression between MDA-MB-231-HPSE and MDA-MB-231-mock cells (A). HPSE expression correlates with IL-10 induced M2 macrophage polarization in a mouse breast tumor model: IHC staining of (B) CD163, (C) VSIG4, and (D) IL-10. 
polarization towards the M2 phenotype by suppressing interferon-gamma, IL-12, and IL-6 production, and upregulating IL-4 and IL-10 production [62-64]. In addition, our clinicopathological parameter analysis indicated that HPSE overexpression is associated with basal-like subtypes, younger age (0-40), advanced SBR grade, advanced NPI grade, and P53 mutated status.

Our previous bioinformatics and experimental studies demonstrated that HPSE promotes malignant progression, angiogenesis and metastasis in breast cancer by enhancing the crosstalk between tumor cells and platelet [65]. In this study, multi-database integration analysis indicated that high HPSE expression contributes to macrophage M2 polarization and $\mathrm{T}$ cell exhaustion, thus promoting tumor growth. These findings were corroborated also by IHC staining of breast tumor tissues; however, since the nude mouse model is not suitable for $\mathrm{T}$ cell analysis, we focused on M2 macrophage polarization. The results indicated that the protein levels of IL-10, CD163, and VSIG4 were significantly increased in breast tumor tissues in mice overexpressing HPSE, indicating that HPSE might promote macrophage M2 polarization (CD163, VSIG4) by upregulating IL-10. Together, our results show that HPSE may serve as a novel biomarker for immune infiltration and prognosis in breast cancer.

\section{MATERIALS AND METHODS}

\section{Analysis of the expression of HPSE}

\section{Oncomine database analysis}

The Oncomine database (http://www.oncomine.org) $[66,67]$ collects transcriptomic cancer data for biomedical study. Using the Oncomine database, the HPSE expression was compared between cancer tissues and their matched normal tissues. The threshold was: $\mathrm{p}$ value $\leq 1 \mathrm{E}-4$, fold change $\geq 2$, and gene rank $\geq$ top $10 \%$.

\section{TIMER database analysis}

TIMER is a database incorporating 10009 samples with 23 cancer types based on TCGA (https://cistrome. shinyapps.io/timer/); HPSE expression in various cancers was compared between cancer tissues and their matched normal tissues.

\section{HPSE and clinical prognosis}

\section{PrognoScan database analysis}

The PrognoScan (http://www.abren.net/PrognoScan/) is an online database used to evaluate the biological relationship between gene expression and prognostic contains overall survival (OS), relapse-free survival (RFS), distant metastasis-free survival (DMFS), disease-specific survival (DSS), and disease-free survival (DFS) in various types of cancers [68], and provide corresponding $\mathrm{p}$-value, hazard ratio (HR), and 95\% confidence intervals. Therefore, it has been used to analyze the correlation between the expression of HPSE and survival in different cancers with the adjusted cox $\mathrm{p}$-value $<0.05$.

\section{GEPIA database analysis}

Gene Expression Profiling Interactive Analysis (GEPIA) (http://gepia.cancer-pku.cn/index.html) is used to perform survival analysis (OS and DFS) depended on RNA sequencing data from TCGA database [69]. And in our study, was used to analyze correlation between HPSE mRNA expression and survival in various types of cancers; HR and log-rank $\mathrm{p}$-values were provided, and the threshold was $\mathrm{p}$-value $<0.05$.

\section{Kaplan-Meier plotter database analysis}

Kaplan-Meier plotter database (http://kmplot.com/ analysis/) is used for analyzing gene association with OS, RFS, DMFS, and post progression survival (PPS) in breast, ovarian, lung and gastric cancer [70]. And in our study, was used to identify the correlation between HPSE mRNA expression and survival in the above four cancer types. The HR and log-rank p-values were provided, and the threshold was p-value $<0.05$.

\section{HPSE and infiltrating immune cells and markers}

\section{TIMER database analysis}

TIMER (https://cistrome.shinyapps.io/timer/) using deconvolution statistical method to analyze the infiltration levels of immune cells including B cells, CD4+ $\mathrm{T}$ cells, CD8+ $\mathrm{T}$ cells, neutrophils, macrophages, and dendritic cells (DCs) based on gene expression profiles [71]. And in our study, was used to analyze the correlation between HPSE expression and the above immune infiltrating cells in bladder and breast cancers, and provided partial correlation coefficients; the threshold was $\mathrm{p}$-value $<0.01$. The absolute value of $\mathrm{R}, 0-0.09$ meant no correlation, 0.1-0.3 meant weak correlation, 0.3-0.5 meant medium correlation, and 0.5-1.0 meant strong correlation.

\section{GEPIA database analysis}

We used GEPIA database to identify the correlation between HPSE and related genes and markers in immune cells. the threshold was $\mathrm{p}$-value $<0.01$; $\mathrm{R}$, 0 0.09 meant no correlation, 0.1-0.3 meant weak correlation, 0.3-0.5 meant medium correlation, and 0.51.0 meant strong correlation. 


\section{HPSE in breast cancer}

\section{Breast cancer gene-expression miner 04.1 database analysis}

Breast Cancer Gene-Expression Miner v4.1 (bcGenExMiner v4.1) [72, 73], was utilized to evaluate the correlation between HPSE expression and clinicopathological parameters in breast cancer.

\section{GO functional annotation analysis}

The database for annotation, visualization, and integrated discovery (DAVID) v.6.8 (https://david. ncifcrf.gov) [74] was used to perform GO [75] functional annotation analyses (positive target genes of HPSE). The background list parameter was human genome, and the threshold was $\mathrm{p}$-value $<0.05$.

\section{In vivo studies}

Human MDA-MB-231-HPSE and MDA-MB-231-mock cells, which represented breast cancer cell lines with high and low expression of HPSE, were handseled by Dr. Israel Vlodavsky, the GFP inserts were performed in Glyconovo Technologies Co., Ltd, and the HPSE expression have been detected between MDA-MB-231HPSE and MDA-MB-231-mock cells by Western blot analysis, and the specific operation method were described previously [65].

Cell culture, animal care, and establishment of a nude mouse model were described previously [65].

The breast tissues were fixed by immersing them in $10 \%$ neutral buffered formalin at room temperature for $24 \mathrm{~h}$, and the paraffin embedding process was performed. Cut the paraffin block of tumor tissue into $5 \mu \mathrm{m}$ sections for IHC staining: The tissue slides were dewaxed in xylene and rehydrated in a graded alcohol bath. Slides were immersed into EDTA antigen extraction buffer and microwaved, and then treated with $3 \%$ hydrogen peroxide in methanol to quench the activity of endogenous peroxidase, and combined with $3 \%$ bovine serum white, the proteins are incubated together to block non-specific binding. Mouse antiCD163 (1:100; 93498S, CST), anti-IL-10 (1:100; ab34843, Abcam), and anti-VSIG4 (1:100; PA5-52018, Thermo) antibodies were incubated overnight at $4^{\circ} \mathrm{C}$, and then incubation with horseradish-peroxidase (HRP)-conjugated secondary antibody. Expression of CD163, IL-10, and VSIG4 in tissues was assessed by two pathologists. The staining outcomes were assessed as the intensity on a scale of 0 to 3; 0 (no staining), 1 (weak staining), 2 (moderate staining), and 3 (strong staining). Positive tumor cell percentage was semiquantitatively assessed on a scale of 0 to 4; 0 (none), 1 $(1-25 \%), 2(26-50 \%), 3(51-75 \%)$, and $4(>75 \%)$.
Histochemical score (H-score) of staining was calculated by multiplying these two variables.

\section{Abbreviations}

HPSE: heparanase; CTLA4: cytotoxic T lymphocyte associated antigen 4; PD-1: programmed death-1; PDL1: programmed death ligand-1; NSCLC: non-smallcell lung carcinoma; TILs: tumor-infiltrating lymphocytes; TME: Tumor microenvironment; HS: heparan sulfate; GO: gene ontology; BLCA: bladder urothelial carcinoma; BRCA: breast invasive carcinoma; CHOL: cholangiocarcinoma; ESCA: esophageal carcinoma; LUAD: lung adenocarcinoma; LUSC: Lung squamous carcinoma; STAD: stomach adenocarcinoma; THCA: thyroid carcinoma; COAD: colon adenocarcinoma; HNSC: head and neck cancer; KIRC: kidney renal clear cell carcinoma; KICH: kidney chromophobe; LIHC: liver hepatocellular carcinoma; PRAD: prostate adenocarcinoma; READ: rectum adenocarcinoma; UCEC: uterine corpus endometrial carcinoma; SBR: Scarff-Bloom-Richardson; NPI: Nottingham Prognostic Index; Akt: phosphorylation of protein kinase B; ERK: extracellular regulated protein kinase; CXCL2: C-X-C motif chemokine ligand 2; VEGF: vascular endothelial growth factor; MSR-2: macrophage scavenger receptor-2; IBD: inflammatory bowel disease; TLRs: Toll-like receptors; TCGA: The Cancer Genome Atlas; OS: overall survival; RFS: relapse-free survival; DMFS: distant metastasis-free survival; DSS: disease-specific survival; DFS: diseasefree survival; HR: hazard ratio; GEPIA: Gene Expression Profiling Interactive Analysis; DCs: dendritic cells; H-score: Histochemical score.

\section{AUTHOR CONTRIBUTIONS}

Conceptualization: Guo-Wang Yang; Methodology: Wen-Jing Yang, Lin Shi; Validation: Wen-Jing Yang; Analysis: Wen-Jing Yang, Lin Shi; Investigation: Wen-Jing Yang, Xiao-Min Wang Data curation: WenJing Yang, Lin Shi; Writing-original draft preparation: Wen-Jing Yang; Writing-review and editing: GuoWang Yang, Xiao-Min Wang; Supervision: Guo-Wang Yang; Project administration: Guo-Wang Yang. Funding acquisition: Guo-Wang Yang and Xiao-Min Wang.

\section{ACKNOWLEDGMENTS}

The authors would like to thank Hai-Bo Wang (Department of Biochemistry and Molecular Biology, Capital Medical University, Beijing, China.) and XinLiu (Beijing Hospital of Traditional Chinese Medicine, Capital Medical University, Beijing, China) for technical support. 


\section{CONFLICTS OF INTEREST}

The authors declare that they have no conflicts of interest.

\section{FUNDING}

This work was supported by the National Natural Science Foundation of China (grant numbers 81774039 , 81673924).

\section{REFERENCES}

1. Fahad Ullah M. Breast Cancer: Current Perspectives on the Disease Status. Adv Exp Med Biol. 2019; 1152: 51-64.

https://doi.org/10.1007/978-3-030-20301-6 4 PMID:31456179

2. Bianchini G, Balko JM, Mayer IA, Sanders ME, Gianni L. Triple-negative breast cancer: challenges and opportunities of a heterogeneous disease. Nat Rev Clin Oncol. 2016; 13:674-90.

https://doi.org/10.1038/nrclinonc.2016.66 PMID:27184417

3. Barbee MS, Ogunniyi A, Horvat TZ, Dang TO. Current status and future directions of the immune checkpoint inhibitors ipilimumab, pembrolizumab, and nivolumab in oncology. Ann Pharmacother. 2015; 49:907-37. https://doi.org/10.1177/1060028015586218 PMID:25991832

4. Ninomiya K, Hotta K. Pembrolizumab for the first-line treatment of non-small cell lung cancer. Expert Opin Biol Ther. 2018; 18:1015-21. https://doi.org/10.1080/14712598.2018.1522300 PMID:30207786

5. Stanton SE, Adams S, Disis ML. Variation in the Incidence and Magnitude of Tumor-Infiltrating Lymphocytes in Breast Cancer Subtypes: A Systematic Review. JAMA Oncol. 2016; 2:1354-60.

https://doi.org/10.1001/jamaoncol.2016.1061 PMID:27355489

6. García-Teijido P, Cabal ML, Fernández IP, Pérez YF. Tumor-Infiltrating Lymphocytes in Triple Negative Breast Cancer: The Future of Immune Targeting. Clin Med Insights Oncol. 2016 (Suppl 1); 10:31-39. https://doi.org/10.4137/CMO.S34540 PMID:27081325

7. Nanda R, Chow LQ, Dees EC, Berger R, Gupta S, Geva R, Pusztai L, Pathiraja K, Aktan G, Cheng JD, Karantza V, Buisseret L. Pembrolizumab in Patients With Advanced Triple-Negative Breast Cancer: Phase Ib KEYNOTE-012 Study. J Clin Oncol. 2016; 34:2460-67. https://doi.org/10.1200/JCO.2015.64.8931 PMID:27138582
8. Adams $S$, Schmid $P$, Rugo HS, Winer EP, Loirat $D$, Awada A, Cescon DW, Iwata H, Campone M, Nanda R, Hui R, Curigliano G, Toppmeyer D, et al. Pembrolizumab monotherapy for previously treated metastatic triple-negative breast cancer: cohort A of the phase II KEYNOTE-086 study. Ann Oncol. 2019; 30:397-404.

https://doi.org/10.1093/annonc/mdy517 PMID:30475950

9. Schmid P, Cortes J, Pusztai L, McArthur H, Kümmel $S$, Bergh J, Denkert C, Park YH, Hui R, Harbeck N, Takahashi M, Foukakis T, Fasching PA, et al, and KEYNOTE-522 Investigators. Pembrolizumab for Early Triple-Negative Breast Cancer. N Engl J Med. 2020; 382:810-21.

https://doi.org/10.1056/NEJMoa1910549 PMID:32101663

10. Adams $S$, Diéras $V$, Barrios $C H$, Winer $E P$, Schneeweiss A, Iwata H, Loi S, Patel S, Henschel V, Chui SY, Rugo HS, Emens LA, Schmid P. Patient-reported outcomes from the phase III IMpassion130 trial of atezolizumab plus nab-paclitaxel in metastatic triple-negative breast cancer. Ann Oncol. 2020; 31:582-89. https://doi.org/10.1016/j.annonc.2020.02.003 PMID:32178964

11. Denkert C, von Minckwitz G, Brase JC, Sinn BV, Gade S, Kronenwett R, Pfitzner BM, Salat C, Loi S, Schmitt WD, Schem C, Fisch K, Darb-Esfahani S, et al. Tumorinfiltrating lymphocytes and response to neoadjuvant chemotherapy with or without carboplatin in human epidermal growth factor receptor 2-positive and triplenegative primary breast cancers. J Clin Oncol. 2015; 33:983-91.

https://doi.org/10.1200/JCO.2014.58.1967 PMID:25534375

12. Adams S, Gray RJ, Demaria S, Goldstein L, Perez EA, Shulman LN, Martino S, Wang M, Jones VE, Saphner TJ, Wolff AC, Wood WC, Davidson NE, et al. Prognostic value of tumor-infiltrating lymphocytes in triplenegative breast cancers from two phase III randomized adjuvant breast cancer trials: ECOG 2197 and ECOG 1199. J Clin Oncol. 2014; 32:2959-66.

https://doi.org/10.1200/JCO.2013.55.0491 PMID:25071121

13. Dieci MV, Mathieu MC, Guarneri V, Conte P, Delaloge $\mathrm{S}$, Andre F, Goubar A. Prognostic and predictive value of tumor-infiltrating lymphocytes in two phase III randomized adjuvant breast cancer trials. Ann Oncol. 2015; 26:1698-704.

https://doi.org/10.1093/annonc/mdv239

PMID:25995301

14. Denkert C, von Minckwitz G, Darb-Esfahani S, Lederer B, Heppner BI, Weber KE, Budczies J, Huober J, 
Klauschen F, Furlanetto J, Schmitt WD, Blohmer JU, Karn $\mathrm{T}$, et al. Tumour-infiltrating lymphocytes and prognosis in different subtypes of breast cancer: a pooled analysis of 3771 patients treated with neoadjuvant therapy. Lancet Oncol. 2018; 19:40-50.

https://doi.org/10.1016/S1470-2045(17)30904-X

PMID:29233559

15. Savas P, Salgado R, Denkert C, Sotiriou C, Darcy PK, Smyth MJ, Loi S. Clinical relevance of host immunity in breast cancer: from TILs to the clinic. Nat Rev Clin Oncol. 2016; 13:228-41.

https://doi.org/10.1038/nrclinonc.2015.215 PMID:26667975

16. Pruneri G, Vingiani A, Denkert C. Tumor infiltrating lymphocytes in early breast cancer. Breast. 2018; 37:207-14.

https://doi.org/10.1016/i.breast.2017.03.010 PMID:28363679

17. Borcherding N, Kolb R, Gullicksrud J, Vikas P, Zhu Y, Zhang W. Keeping Tumors in Check: A Mechanistic Review of Clinical Response and Resistance to Immune Checkpoint Blockade in Cancer. J Mol Biol. 2018; 430:2014-29.

https://doi.org/10.1016/j.jmb.2018.05.030

PMID:29800567

18. Lim YZ, South AP. Tumour-stroma crosstalk in the development of squamous cell carcinoma. Int J Biochem Cell Biol. 2014; 53:450-58.

https://doi.org/10.1016/j.biocel.2014.06.012 PMID:24955488

19. Quail DF, Joyce JA. Microenvironmental regulation of tumor progression and metastasis. Nat Med. 2013; 19:1423-37.

https://doi.org/10.1038/nm.3394 PMID:24202395

20. Joyce JA, Pollard JW. Microenvironmental regulation of metastasis. Nat Rev Cancer. 2009; 9:239-52.

https://doi.org/10.1038/nrc2618

PMID:19279573

21. Yin $Y$, Yao $S$, Hu Y, Feng $Y$, Li M, Bian Z, Zhang J, Qin $Y$, Qi X, Zhou L, Fei B, Zou J, Hua D, Huang Z. The Immunemicroenvironment Confers Chemoresistance of Colorectal Cancer through Macrophage-Derived IL6. Clin Cancer Res. 2017; 23:7375-87.

https://doi.org/10.1158/1078-0432.CCR-17-1283

PMID:28928161

22. Hanahan D, Weinberg RA. Hallmarks of cancer: the next generation. Cell. 2011; 144:646-74.

https://doi.org/10.1016/i.cell.2011.02.013 PMID:21376230

23. Cammarota R, Bertolini V, Pennesi G, Bucci EO, Gottardi O, Garlanda C, Laghi L, Barberis MC, Sessa F, Noonan DM, Albini A. The tumor microenvironment of colorectal cancer: stromal TLR-4 expression as a potential prognostic marker. J Transl Med. 2010; 8:112. https://doi.org/10.1186/1479-5876-8-112 PMID:21059221

24. Hammond E, Khurana A, Shridhar V, Dredge K. The Role of Heparanase and Sulfatases in the Modification of Heparan Sulfate Proteoglycans within the Tumor Microenvironment and Opportunities for Novel Cancer Therapeutics. Front Oncol. 2014; 4:195. https://doi.org/10.3389/fonc.2014.00195 PMID:25105093

25. Zheng LD, Tong QS, Tang ST, Du ZY, Liu Y, Jiang GS, Cai $J B$. Expression and clinical significance of heparanase in neuroblastoma. World J Pediatr. 2009; 5:206-10. https://doi.org/10.1007/s12519-009-0039-9 PMID:19693465

26. Rivara S, Milazzo FM, Giannini G. Heparanase: a rainbow pharmacological target associated to multiple pathologies including rare diseases. Future Med Chem. 2016; 8:647-80. https://doi.org/10.4155/fmc-2016-0012 PMID:27057774

27. Vlodavsky I, Beckhove P, Lerner I, Pisano C, Meirovitz A, Ilan N, Elkin M. Significance of heparanase in cancer and inflammation. Cancer Microenviron. 2012; 5:115-32. https://doi.org/10.1007/s12307-011-0082-7 PMID:21811836

28. Gomes AM, Stelling MP, Pavão MS. Heparan sulfate and heparanase as modulators of breast cancer progression. Biomed Res Int. 2013; 2013:852093. https://doi.org/10.1155/2013/852093 PMID:23984412

29. Edovitsky E, Elkin M, Zcharia E, Peretz T, Vlodavsky I. Heparanase gene silencing, tumor invasiveness, angiogenesis, and metastasis. J Natl Cancer Inst. 2004; 96:1219-30.

https://doi.org/10.1093/jnci/djh230

PMID:15316057

30. Yang $Y$, Macleod $V$, Bendre $M$, Huang $Y$, Theus AM, Miao HQ, Kussie P, Yaccoby S, Epstein J, Suva LJ, Kelly $T$, Sanderson RD. Heparanase promotes the spontaneous metastasis of myeloma cells to bone. Blood. 2005; 105:1303-09.

https://doi.org/10.1182/blood-2004-06-2141 PMID:15471949

31. Shteingauz A, Boyango I, Naroditsky I, Hammond E, Gruber M, Doweck I, Ilan N, Vlodavsky I. Heparanase Enhances Tumor Growth and Chemoresistance by Promoting Autophagy. Cancer Res. 2015; 75:3946-57. https://doi.org/10.1158/0008-5472.CAN-15-0037 PMID:26249176

32. Ramani VC, Zhan F, He J, Barbieri P, Noseda A, Tricot G, Sanderson RD. Targeting heparanase overcomes 
chemoresistance and diminishes relapse in myeloma.

Oncotarget. 2016; 7:1598-607.

https://doi.org/10.18632/oncotarget.6408

PMID:26624982

33. Mayfosh AJ, Baschuk N, Hulett MD. Leukocyte Heparanase: A Double-Edged Sword in Tumor Progression. Front Oncol. 2019; 9:331. https://doi.org/10.3389/fonc.2019.00331 PMID:31110966

34. Theodoro TR, de Matos LL, Sant Anna AV, Fonseca FL, Semedo P, Martins LC, Nader HB, Del Giglio A, da Silva Pinhal MA. Heparanase expression in circulating lymphocytes of breast cancer patients depends on the presence of the primary tumor and/or systemic metastasis. Neoplasia. 2007; 9:504-10.

https://doi.org/10.1593/neo.07241 PMID:17603633

35. Gohji K, Okamoto M, Kitazawa S, Toyoshima M, Dong J, Katsuoka Y, Nakajima M. Heparanase protein and gene expression in bladder cancer. J Urol. 2001; 166: 1286-90.

PMID:11547059

36. Shafat I, Pode D, Peretz T, Ilan N, Vlodavsky I, Nisman B. Clinical significance of urine heparanase in bladder cancer progression. Neoplasia. 2008; 10:125-30. https://doi.org/10.1593/neo.07875 PMID:18283334

37. Zhao W, Wang XS, Niu HT, Wang LL, Han BM, Xia SJ. Clinical relevance of heparanase mRNA expression in bladder cancer and its usefulness as a detection marker in voided urine. Mol Med Rep. 2009; 2:327-31. https://doi.org/10.3892/mmr 00000104 PMID:21475833

38. Tatsumi $Y$, Miyake M, Shimada K, Fujii T, Hori S, Morizawa Y, Nakai Y, Anai S, Tanaka N, Konishi N, Fujimoto K. Inhibition of Heparanase Expression Results in Suppression of Invasion, Migration and Adhesion Abilities of Bladder Cancer Cells. Int J Mol Sci. 2020; 21:3789.

https://doi.org/10.3390/ijms21113789

PMID:32471161

39. Hermano E, Goldberg R, Rubinstein AM, Sonnenblick A, Maly B, Nahmias D, Li JP, Bakker MA, van der Vlag J, Vlodavsky I, Peretz T, Elkin M. Heparanase Accelerates Obesity-Associated Breast Cancer Progression. Cancer Res. 2019; 79:5342-54.

https://doi.org/10.1158/0008-5472.CAN-18-4058 PMID:31481501

40. Vornicova O, Naroditsky I, Boyango I, Shachar SS, Mashiach T, Ilan N, Vlodavsky I, Bar-Sela G. Prognostic significance of heparanase expression in primary and metastatic breast carcinoma. Oncotarget. 2017; 9:6238-44.

https://doi.org/10.18632/oncotarget.23560

PMID:29464068
41. Crispel $Y$, Axelman E, Tatour M, Kogan I, Nevo N, Brenner B, Nadir Y. Peptides inhibiting heparanase procoagulant activity significantly reduce tumour growth and vascularisation in a mouse model. Thromb Haemost. 2016; 116:669-78.

https://doi.org/10.1160/TH16-02-0119

PMID:27535490

42. Wu YJ, Hsu WJ, Wu LH, Liou HP, Pangilinan CR, Tyan YC, Lee $\mathrm{CH}$. Hinokitiol reduces tumor metastasis by inhibiting heparanase via extracellular signal-regulated kinase and protein kinase B pathway. Int J Med Sci. 2020; 17:403-13.

https://doi.org/10.7150/ijms.41177

PMID:32132875

43. Singh R, Mishra MK, Aggarwal H. Inflammation, Immunity, and Cancer. Mediators Inflamm. 2017; 2017:6027305.

https://doi.org/10.1155/2017/6027305

PMID:29234189

44. Mantovani A, Sica A. Macrophages, innate immunity and cancer: balance, tolerance, and diversity. Curr Opin Immunol. 2010; 22:231-37.

https://doi.org/10.1016/j.coi.2010.01.009

PMID:20144856

45. Biswas SK, Sica A, Lewis CE. Plasticity of macrophage function during tumor progression: regulation by distinct molecular mechanisms. J Immunol. 2008; 180:2011-17.

https://doi.org/10.4049/jimmunol.180.4.2011 PMID:18250403

46. De Palma $M$, Lewis CE. Macrophage regulation of tumor responses to anticancer therapies. Cancer Cell. 2013; 23:277-86.

https://doi.org/10.1016/j.ccr.2013.02.013

PMID:23518347

47. Biswas SK, Mantovani A. Macrophage plasticity and interaction with lymphocyte subsets: cancer as a paradigm. Nat Immunol. 2010; 11:889-96.

https://doi.org/10.1038/ni.1937

PMID:20856220

48. Zebedin E, Freissmuth M, Sexl V. Signal interceptionbased therapies--a double-edged sword in Bcr/ablinduced malignancies? Leuk Lymphoma. 2008; 49: 620-24.

https://doi.org/10.1080/10428190701858872

PMID:18398721

49. Soloviev DA, Hazen SL, Szpak D, Bledzka KM, Ballantyne CM, Plow EF, Pluskota E. Dual role of the leukocyte integrin $\alpha \mathrm{M} \beta 2$ in angiogenesis. J Immunol. 2014; 193:4712-21.

https://doi.org/10.4049/jimmunol.1400202

PMID:25261488 
50. Mills CD, Lenz LL, Harris RA. A Breakthrough: Macrophage-Directed Cancer Immunotherapy. Cancer Res. 2016; 76:513-16.

https://doi.org/10.1158/0008-5472.CAN-15-1737 PMID:26772756

51. Nielsen SR, Schmid MC. Macrophages as Key Drivers of Cancer Progression and Metastasis. Mediators Inflamm. 2017; 2017:9624760.

https://doi.org/10.1155/2017/9624760

PMID:28210073

52. Cersosimo F, Lonardi S, Bernardini G, Telfer B, Mandelli GE, Santucci A, Vermi W, Giurisato E. TumorAssociated Macrophages in Osteosarcoma: From Mechanisms to Therapy. Int J Mol Sci. 2020; 21:5207. https://doi.org/10.3390/ijms21155207 PMID:32717819

53. Gutter-Kapon L, Alishekevitz D, Shaked Y, Li JP, Aronheim A, llan N, Vlodavsky I. Heparanase is required for activation and function of macrophages. Proc Natl Acad Sci USA. 2016; 113:E7808-17. https://doi.org/10.1073/pnas.1611380113 PMID:27849593

54. Hermano E, Meirovitz A, Meir K, Nussbaum G, Appelbaum L, Peretz T, Elkin M. Macrophage polarization in pancreatic carcinoma: role of heparanase enzyme. J Natl Cancer Inst. 2014; 106:dju332.

https://doi.org/10.1093/jnci/dju332

PMID:25326645

55. Lerner I, Hermano E, Zcharia E, Rodkin D, Bulvik R, Doviner V, Rubinstein AM, Ishai-Michaeli R, Atzmon R, Sherman Y, Meirovitz A, Peretz T, Vlodavsky I, Elkin M. Heparanase powers a chronic inflammatory circuit that promotes colitis-associated tumorigenesis in mice. J Clin Invest. 2011; 121:1709-21. https://doi.org/10.1172/JCl43792 PMID:21490396

56. Khamaysi I, Singh P, Nasser S, Awad H, Chowers $Y$, Sabo E, Hammond E, Gralnek I, Minkov I, Noseda A, Ilan N, Vlodavsky I, Abassi Z. The Role of Heparanase in the Pathogenesis of Acute Pancreatitis: A Potential Therapeutic Target. Sci Rep. 2017; 7:715. https://doi.org/10.1038/s41598-017-00715-6 PMID:28386074

57. Brun R, Naroditsky I, Waterman M, Ben-Izhak O, Groisman G, Ilan N, Vlodavsky I. Heparanase expression by Barrett's epithelium and during esophageal carcinoma progression. Mod Pathol. 2009; 22:1548-54.

https://doi.org/10.1038/modpathol.2009.115 PMID:19749739

58. Bhattacharya U, Gutter-Kapon L, Kan T, Boyango I, Barash U, Yang SM, Liu J, Gross-Cohen M, Sanderson
RD, Shaked Y, Ilan N, Vlodavsky I. Heparanase and Chemotherapy Synergize to Drive Macrophage Activation and Enhance Tumor Growth. Cancer Res. 2020; 80:57-68.

https://doi.org/10.1158/0008-5472.CAN-19-1676 PMID:31690669

59. Lesina M, Kurkowski MU, Ludes K, Rose-John S, Treiber M, Klöppel G, Yoshimura A, Reindl W, Sipos B, Akira S, Schmid RM, Algül H. Stat3/Socs3 activation by IL-6 transsignaling promotes progression of pancreatic intraepithelial neoplasia and development of pancreatic cancer. Cancer Cell. 2011; 19:456-69.

https://doi.org/10.1016/j.ccr.2011.03.009

PMID:21481788

60. Blich M, Golan A, Arvatz G, Sebbag A, Shafat I, Sabo E, Cohen-Kaplan V, Petcherski S, Avniel-Polak S, Eitan A, Hammerman $\mathrm{H}$, Aronson D, Axelman $\mathrm{E}$, et al. Macrophage activation by heparanase is mediated by TLR-2 and TLR-4 and associates with plaque progression. Arterioscler Thromb Vasc Biol. 2013; 33:e56-65.

https://doi.org/10.1161/ATVBAHA.112.254961

PMID:23162016

61. Goodall KJ, Poon IK, Phipps S, Hulett MD. Soluble heparan sulfate fragments generated by heparanase trigger the release of pro-inflammatory cytokines through TLR-4. PLoS One. 2014; 9:e109596. https://doi.org/10.1371/journal.pone.0109596 PMID:25295599

62. Campbell MJ, Tonlaar NY, Garwood ER, Huo D, Moore DH, Khramtsov Al, Au A, Baehner F, Chen Y, Malaka DO, Lin A, Adeyanju OO, Li S, et al. Proliferating macrophages associated with high grade, hormone receptor negative breast cancer and poor clinical outcome. Breast Cancer Res Treat. 2011; 128:703-11. https://doi.org/10.1007/s10549-010-1154-y PMID:20842526

63. Kratochvill F, Neale G, Haverkamp JM, Van de Velde LA, Smith AM, Kawauchi D, McEvoy J, Roussel MF, Dyer MA, Qualls JE, Murray PJ. TNF Counterbalances the Emergence of M2 Tumor Macrophages. Cell Rep. 2015; 12:1902-14.

https://doi.org/10.1016/i.celrep.2015.08.033 PMID:26365184

64. Mantovani A, Marchesi F, Malesci A, Laghi L, Allavena P. Tumour-associated macrophages as treatment targets in oncology. Nat Rev Clin Oncol. 2017; 14: 399-416.

https://doi.org/10.1038/nrclinonc.2016.217 PMID:28117416

65. Yang WJ, Zhang GL, Cao KX, Liu XN, Wang XM, Yu MW, Li JP, Yang GW. Heparanase from triple-negative breast 
cancer and platelets acts as an enhancer of metastasis. Int J Oncol. 2020; 57:890-904.

https://doi.org/10.3892/ijo.2020.5115 PMID:32945393

66. Rhodes DR, Yu J, Shanker K, Deshpande N, Varambally R, Ghosh D, Barrette T, Pandey A, Chinnaiyan AM. ONCOMINE: a cancer microarray database and integrated data-mining platform. Neoplasia. 2004; 6:1-6.

https://doi.org/10.1016/s1476-5586(04)80047-2

PMID:15068665

67. Rhodes DR, Kalyana-Sundaram S, Mahavisno V, Varambally R, Yu J, Briggs BB, Barrette TR, Anstet MJ, Kincead-Beal C, Kulkarni P, Varambally S, Ghosh D, Chinnaiyan AM. Oncomine 3.0: genes, pathways, and networks in a collection of 18,000 cancer gene expression profiles. Neoplasia. 2007; 9:166-80. https://doi.org/10.1593/neo.07112 PMID:17356713

68. Mizuno H, Kitada K, Nakai K, Sarai A. PrognoScan: a new database for meta-analysis of the prognostic value of genes. BMC Med Genomics. 2009; 2:18. https://doi.org/10.1186/1755-8794-2-18 PMID:19393097

69. Tang Z, Li C, Kang B, Gao G, Li C, Zhang Z. GEPIA: a web server for cancer and normal gene expression profiling and interactive analyses. Nucleic Acids Res. 2017; 45:W98-102.

https://doi.org/10.1093/nar/gkx247

PMID:28407145

70. Lánczky A, Nagy Á, Bottai G, Munkácsy G, Szabó A, Santarpia L, Győrffy B. miRpower: a web-tool to validate survival-associated miRNAs utilizing expression data from 2178 breast cancer patients. Breast Cancer Res Treat. 2016; 160:439-46. https://doi.org/10.1007/s10549-016-4013-7 PMID:27744485
71. Li T, Fan J, Wang B, Traugh N, Chen Q, Liu JS, Li B, Liu XS. TIMER: A Web Server for Comprehensive Analysis of Tumor-Infiltrating Immune Cells. Cancer Res. 2017; 77:e108-10.

https://doi.org/10.1158/0008-5472.CAN-17-0307

PMID:29092952

72. Jézéquel $P$, Campone $M$, Gouraud $W$, GuérinCharbonnel C, Leux C, Ricolleau G, Campion L. bcGenExMiner: an easy-to-use online platform for gene prognostic analyses in breast cancer. Breast Cancer Res Treat. 2012; 131:765-75.

https://doi.org/10.1007/s10549-011-1457-7

PMID:21452023

73. Jézéquel $P$, Frénel JS, Campion L, Guérin-Charbonnel $C$, Gouraud W, Ricolleau G, Campone M. bc-GenExMiner 3.0: new mining module computes breast cancer gene expression correlation analyses. Database (Oxford). 2013; 2013:bas060.

https://doi.org/10.1093/database/bas060

PMID:23325629

74. Dennis G Jr, Sherman BT, Hosack DA, Yang J, Gao W, Lane HC, Lempicki RA. DAVID: Database for Annotation, Visualization, and Integrated Discovery. Genome Biol. 2003; 4:P3.

PMID: 12734009

75. Ashburner M, Ball CA, Blake JA, Botstein D, Butler $H$, Cherry JM, Davis AP, Dolinski K, Dwight SS, Eppig JT, Harris MA, Hill DP, Issel-Tarver $L$, et al. Gene ontology: tool for the unification of biology. The Gene Ontology Consortium. Nat Genet. 2000; 25:25-29.

https://doi.org/10.1038/75556

PMID:10802651 